\title{
Knowledge and Adherence to Oral Anticoagulant Therapy among Patients with Mechanical Heart Valve Prosthesis
}

\author{
Amany Youssef Sharaf ${ }^{1}$, Alyaa Farouk Abd El-Fattah Ibrahim ${ }^{2,3}$, Moustafa \\ Elhamami ${ }^{4}$ \\ ${ }^{1}$.Lecturer of Medical-Surgical Nursing, Faculty of Nursing, Alexandria University, Egypt \\ 2. Lecturer of Community Health Nursing, Faculty of Nursing, Alexandria University, Egypt \\ ${ }^{3 .}$ Assist. Professor of Community Health Nursing, College of Nursing, King Saud bin Abdul-Aziz University for \\ Health Sciences. KSA \\ 4. Professor of cardio-thoracic surgery, Faculty of Medicine, Alexandria University- Egypt
}

\begin{abstract}
Background: Patients with mechanical valve implantation require lifelong oral anticoagulant therapy to allow adequate valve function and prevent thromboembolic risk. Being on such high alert therapy necessitates knowledge and adherence to avoid major complications.

Objectives: this study aims to determine the knowledge and adherence to oral anticoagulant therapy among patients with mechanical heart valve prosthesis.

Setting: Cardiothoracic Outpatient Clinic of Alexandria Main University Hospital, Alexandria, Egypt.

Materials and Methods: This is a descriptive study. Data was collected from 75 mechanical valve prosthesis patients attending the pre-mentioned health setting. A socio demographic, clinical characteristics structured questionnaire, Patients' knowledge about Oral Anticoagulant Therapy structured interview questionnaire and Patient oral anticoagulant therapy adherence structured interview questionnaire were developed by the researchers and used for data collection. Each patient was interviewed individually for about 30 minutes after brief explanation of the study objective and assuring information confidentiality.

Results: Female patients (56\%) exceeded males (44\%), the mean age was $46.48 \pm 9.38$. Only $41.3 \%$ of the studied patients received education regarding oral anticoagulants by their physician. $66.7 \%$ of the studied patients had moderate overall knowledge score, while less than half of them had either satisfactory or good adherence levels $(42.7 \%$, and $44 \%$ respectively). There were positive significant correlations between patients' adherence to Oral Anticoagulants and their level of knowledge $(r=0.597 *, p=<0.001 *)$. There were significant differences between patient's education, sex, occupation and their level of knowledge, whereas no significance differences between patient's sex/age and their level of adherence were found.

Conclusion: The majority of the studied patients had moderate overall knowledge score about Oral Anticoagulants, and less than half of them had either satisfactory or good adherence levels. There were positive significant correlations between patients' adherence to Oral Anticoagulants and their level of knowledge

Recommendations: An in-service educational program regarding OAC therapy should be provided for nurses working at the cardiovascular units to update their knowledge and practice about OAC therapy.
\end{abstract}

Keywords: Oral anticoagulant therapy, mechanical heart valve prosthesis, knowledge, drug adherence

\section{Introduction}

Cardiovascular diseases are considered the most worldwide epidemic disease, causing over 17.5 million losses annually ${ }^{[1,2]}$.In Egypt, out of the 523,000 deaths in 2014, it was estimated that cardiovascular diseases account for $46 \%$ of the total number of those mortalities ${ }^{[3]}$. One of the major categories of cardiovascular diseases is Valvular Heart Disorders (VHD) ${ }^{[4]}$. Valvular heart diseases are defined as any disease process that involve one or more of the four valves of the heart ${ }^{[5]}$. This condition occurs mostly due to aging, congenital abnormalities, specific disease or physiologic processes including rheumatic heart disease and pregnancy ${ }^{[6]}$. Heart valve replacement is considered the most effective and the final management for this category of diseases ${ }^{[7]}$.The potential for morbidity and mortality from a valvular prosthesis remains as long as the valve is in place. Patients with mechanical valve implantation require lifelong oral anticoagulant (OAC) therapy to allow adequate valve function and prevent thromboembolic risk ${ }^{[8-10]}$

Oral anticoagulant medication is one of the most widely prescribed drugs all over the world ${ }^{[11]}$. As $\mathrm{OAC}$ is a long life therapy, it requires knowledge and adherence to avoid fatal complications ${ }^{[12,13]}$. Adverse OAC related complications are blamed for an estimated 34,000 fatal or life threatening events annually, and the majority of those serious events are preventable ${ }^{[14]}$. Literature review revealed that $\mathrm{OAC}$ is one of the drugs that mostly associated with emergency department visits, hospitalization and death ${ }^{[15]}$.

DOI: 10.9790/1959-0603021929 $\quad$ www.iosrjournals.org $\quad 19 \mid$ Page


Multiple factors influence OAC metabolism and can significantly affect the risk of adverse events ${ }^{[16]}$. Patient-related factors include lack of knowledge about anticoagulation therapy, its side effects, drug interactions, drug precautions, importance of laboratory testing, and follow up. Diet knowledge is also necessary, particularly for foods that contain vitamin $\mathrm{K}^{[16,17]}$.

Poor medication adherence is considered an important concern of the community, as it leads to increased morbidities, mortalities and healthcare costs ${ }^{[18,19,20]}$. WHO reported that adherence among patients with chronic diseases averages only $50 \%$ in developed countries ${ }^{[21]}$. Non adherence with OAC leads to serious consequences such as; bleeding, stroke, thromboembolism, cardiovascular complications and sudden cardiac arrest $^{[17]}$. Considering OAC a high alert medication necessitates equipping patients with adequate knowledge in order to ensure patients' safety and reduce probability of complications development ${ }^{[20]}$. Also, improving medication adherence is another vital aspect in clinical practice and research that is linked to high controlled coagulation ${ }^{[21]}$

As OAC is a life-saving drug, nurses have a unique role in caring for patients undertaking long-life anticoagulant therapy. Nurses are responsible for supplying their patients with the necessary knowledge related to the therapy regimen and its side effects to ensure the full benefits of the drug, and eliminates potential complications. In addition. nurses are responsible for screening their patients for any medication allergies before initiation of treatment, then, monitor the effectiveness of the therapy, patient's therapy adherence, and potential side effects ${ }^{[20,22,23]}$. So, this study aims to determine the knowledge and adherence to oral anticoagulant therapy among patients with mechanical heart valve prosthesis.

\section{MATERIALS}

\section{Materials And Method}

Research questions: Do patients with mechanical heart valves prosthesis have the appropriate knowledge regarding OAC therapy? And do they adhere to their prescribed therapy?

Design: A descriptive research design was used for the purpose of study.

Settings: This study was conducted at the Cardiothoracic Outpatient Clinic of Alexandria Main University Hospital, Alexandria, Egypt.

Subjects: The study comprised a convenience sample of 75 patients with mechanical heart valve prosthesis, attending the pre-mentioned health setting and meeting the following inclusion criteria:

- Adult (age 20- 60 years old)

- On Oral Anticoagulants therapy for duration of at least 6 months

- Attend at the pre-mentioned outpatient clinic for follow-up

Sample size calculation: Epi info -7 programs was used to estimate the sample size using the following parameters:

1- Population size $=90$ patients over 3 months

2- Expected frequency $=50 \%$

3 -Acceptable error $=5 \%$

4-Confidence co efficient $=95 \%$

5-Minimum sample size $=73$ patients

Tools: based on an extensive review of related literature; three tools were used for the purpose of data collection.

Tool I: Socio demographic and clinical characteristics structured questionnaire: It includes questions related to the socio demographic characteristics of the studied patients (age, sex, education, occupation, social status, area of residence) and questions related to the clinical characteristics of the studied patients (Date of the surgery, position of prosthesis, duration of anticoagulant usage, receiving OAC education).

Tool II: Patients' knowledge about Oral Anticoagulant Therapy structured interview questionnaire: A three point likert scale was developed by researchers in accordance with the relevant literatures to determine the patients' level of knowledge regarding OAC ${ }^{[24-27]}$. The questionnaire included 19 questions. 8 questions for OAC information, 1 question for drug side effects, 3 for drug precautions, 2 for drug interaction, 2 for food interaction, and 3 for international normalized ratio level (INR) monitoring.

Each question had 3 possible options, "know", "partly know", and "don't know". The average scores were calculated by assigning a score of 2 to the know/correct answers and a score of 1 to the partly know/partly correct answer, and 0 to the don't know/incorrect answers. The minimum score patients could receive was 0 while the maximum was 38 . Then the total scores were evaluated and put into one of three categories:

- High knowledge $(\geq 75 \%)$

- Moderate knowledge $(50<75 \%)$ 
- Low knowledge $(>50 \%)$

Tool III: Patients' OAC adherence structured interview questionnaire: It was developed by the researchers to evaluate patients 'adherence to OAC after review of relevant literatures ${ }^{[23-25]}$.It included 6 questions focused on monitoring INR test, and forgetting, delaying, or doubling the drug dose. Questions were answered as yes and No and scored one point for yes and zero point for No. Scores were summed to give a total score, ranging from 0 to 6 . A score more than zero is defined as non adherence. The total scores were evaluated and put into one of three categories:

- Unsatisfactory level of adherence $(<50 \%)$

- Satisfactory level of adherence $(50 \geq 75 \%)$

- Good level of adherence (> $75 \%$ )

\section{Method}

Ethical considerations: Approval for conducting this study was given by the Research Institutional Review Board of the Faculty of Nursing, Alexandria University. Afterwards, study setting director's permission to carry out the study was obtained after explaining the study objective. Aim of the study was explained to all participants, and all of them signed the informed consent before participation. Patients were assured about the confidentiality and freedom to participate in the study. Then, data were coded to eliminate any identifying or personal information.

Tools were developed by the researchers after extensive review of relevant literatures. Content and construct validity of the tools were ascertained by a jury of 5 experts in the fields of medical surgical nursing, community health nursing and cardiology. Necessary modifications were done accordingly. Internal consistency was used in ascertaining reliability of tool $1(\mathrm{r}=0.70)$ and of tool II $(\mathrm{r}=0.72)$ using Cronbach Alpha Coefficient Test.

Pilot study: Tools were pre-tested on 8 mechanical valve prosthesis patients who were not included in the study sample. After analyzing the data obtained from the pilot study, some modifications were introduced accordingly.

Data collection: Every patient was interviewed individually for an average period of 30 minutes after brief explanation of the aim of the study. Data was collected over a period of 3 months starting from September to end of November 2016.

Statistical analysis: After data collection, they were coded, transferred into a specially designed format to be suitable for computer feeding, then entered, checked, and verified to avoid any error during data entry. Statistical analysis was performed using Statistical package for Social Sciences (SPSS version 20). The level of significance selected for this study was $\mathrm{p}$ equal to or less than 0.05 .

The used tests were

1 - Chi-square test: For categorical variables, to compare between different groups

2 - Monte Carlo correction: Correction for chi-square when more than $20 \%$ of the cells have expected count less than 5

3 - Pearson coefficient: To correlate between two normally distributed quantitative variables

\section{Results}

Table (1): Illustrates that female patients (56\%) exceed males (44\%). The mean age is $46.48 \pm 9.38$ years. The majority of the studied patients $(89.3 \%$ ) are married, while only $9.3 \%$ of them hold bachelor degree. The majority $(41.3 \%)$ of the studied populations are house wives, while $30.7 \%$ of them have technical work. Also, the majority of them $(86.7 \%)$ live in urban areas. Nearly half of the studied patients have mitral valve, and receive OAC for less than one year (49.3\% \& 46.7\%, respectively). Only $41.3 \%$ of the studied patients received education regarding $\mathrm{OAC}$ by their physician, while $58.7 \%$ did not receive any education about OAT.

Table (1): Distribution of the studied patients according to their socio-demographic and clinical characteristics $(n=75)$

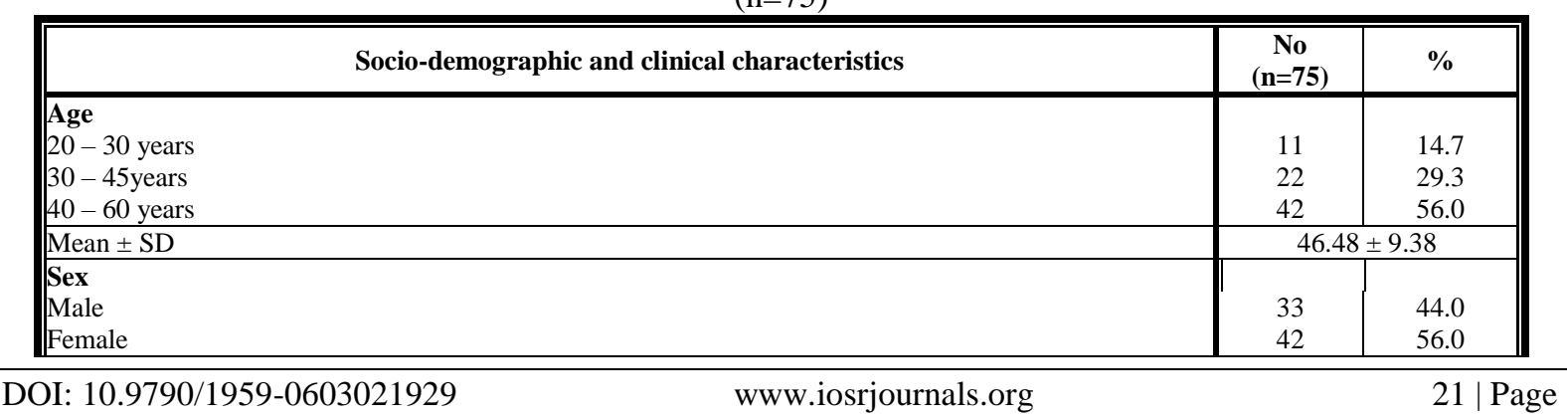




\begin{tabular}{|c|c|c|}
\hline \begin{tabular}{|l|} 
Education level \\
Illiterate \\
Read, write \\
Diploma \\
Bachelor
\end{tabular} & $\begin{array}{l}29 \\
22 \\
17 \\
7\end{array}$ & $\begin{array}{c}38.7 \\
29.3 \\
22.7 \\
9.3\end{array}$ \\
\hline \begin{tabular}{|l|} 
Occupation \\
Clerical \\
Technical \\
Housewife \\
Retired \\
Not working \\
\end{tabular} & $\begin{array}{c}9 \\
23 \\
31 \\
8 \\
4 \\
\end{array}$ & $\begin{array}{c}12.0 \\
30.7 \\
41.3 \\
10.7 \\
5.3 \\
\end{array}$ \\
\hline \begin{tabular}{|l|} 
Social status \\
Single \\
Married \\
Divorced \\
\end{tabular} & $\begin{array}{c}6 \\
67 \\
2 \\
\end{array}$ & $\begin{array}{c}8.0 \\
89.3 \\
2.7\end{array}$ \\
\hline \begin{tabular}{|l|} 
Residence \\
Urban \\
Rural \\
\end{tabular} & $\begin{array}{l}65 \\
10 \\
\end{array}$ & $\begin{array}{l}86.7 \\
13.3 \\
\end{array}$ \\
\hline \begin{tabular}{|l|} 
Position of prosthesis \\
Mitral \\
Aortic \\
Both \\
\end{tabular} & $\begin{array}{l}37 \\
23 \\
15\end{array}$ & $\begin{array}{l}49.3 \\
30.7 \\
20.0\end{array}$ \\
\hline $\begin{array}{l}\text { Duration of anticoagulant usage } \\
>1 \text { year } \\
1-5 \text { years } \\
55 \text { years }\end{array}$ & $\begin{array}{c}35 \\
33 \\
7 \\
\end{array}$ & $\begin{array}{c}46.7 \\
44.0 \\
9.3\end{array}$ \\
\hline $\begin{array}{l}\text { Received of anticoagulant education } \\
\text { Yes } \\
\text { No }\end{array}$ & $\begin{array}{l}31 \\
44 \\
\end{array}$ & $\begin{array}{r}41.3 \\
58.7 \\
\end{array}$ \\
\hline $\begin{array}{l}\text { Source of education }(\mathbf{n}=\mathbf{3 1}) \\
\text { Physician } \\
\text { Nurse }\end{array}$ & $\begin{array}{c}31 \\
0 \\
\end{array}$ & $\begin{array}{c}100.0 \\
0.0\end{array}$ \\
\hline
\end{tabular}

Table (2) Shows that most of the studied patients are able to recall the name of OAC, and precautions to the drug they were using, the mean percent scores of patients' knowledge related to drug information and to drug precautions are $78.57 \pm 15.04$, and $83.56 \pm 15.62$ respectively. When asked about side effects of the oral anticoagulants, an expressive number of patients $(69.3 \%)$ were not able to mention at least two side effects of the drug. The mean percent knowledge scores related to drug interaction and the influence of diet rich in vitamin $\mathrm{K}$ are $56.0 \pm 42.48$, and $13.33 \pm 20.27$ respectively. Also, the majority of patients $(78.7 \%)$ mentioned monthly laboratorial control as the main necessary care.

Table (2): Distribution of the studied patients according to their level of knowledge related to OAC $(\mathrm{n}=75)$

\begin{tabular}{|c|c|c|c|c|c|c|c|}
\hline \multirow{2}{*}{ Area of patients' knowledge } & \multicolumn{2}{|c|}{ Know } & \multicolumn{2}{|c|}{ Partly know } & \multicolumn{2}{|c|}{ Don't know } & \multirow{2}{*}{ Mean \% score } \\
\hline & No. & $\%$ & No. & $\%$ & No. & $\%$ & \\
\hline OAC information & & & & & & & \\
\hline - The name of your anticoagulant medicine is & 67 & 89.3 & - & - & 8 & 10.7 & \\
\hline How does this medicine work in your body?(action) & 14 & 18.7 & 27 & 36.0 & 34 & 45.3 & \\
\hline For how long do you need to take this medicine & 55 & 73.3 & - & - & 20 & 26.7 & \\
\hline $\begin{array}{l}\text { It is important to take this medicine at the same } \\
\text { time each day? }\end{array}$ & 61 & 81.3 & - & - & 14 & 18.7 & \\
\hline $\begin{array}{l}\text { Different doses of OAC can be identified through } \\
\text { their colors }\end{array}$ & 64 & 85.4 & - & - & 11 & 14.6 & $78.57 \pm 15.04$ \\
\hline $\begin{array}{l}\text { When a dose is missed, the next dose should be } \\
\text { taken }\end{array}$ & 62 & 82.7 & - & - & 13 & 17.3 & \\
\hline $\begin{array}{l}\text { It is okay to double the next dose of this medicine if } \\
\text { you miss a dose }\end{array}$ & 69 & 92.0 & - & - & 6 & 8.0 & \\
\hline $\begin{array}{l}\text { It is appropriate to reduce the dose or/stop taking } \\
\text { this medicine once you feel better }\end{array}$ & 62 & 82.7 & - & - & 13 & 17.3 & \\
\hline $\begin{array}{l}\text { Side effects } \\
\text { Mention at least two side effect of OAC } \\
\text { therapy(skin bruising, gum bleeding, melena, } \\
\text { hematemesis, vaginal bleeding) }\end{array}$ & 7 & 9.3 & 16 & 21.4 & 52 & 69.3 & $20.0 \pm 32.88$ \\
\hline $\begin{array}{l}\text { Drug Precautions } \\
\text { The patient should inform a surgeon, dentist that he } \\
\text { is receiving OAC before undergoing surgery or a } \\
\text { procedure } \\
\text { - Patients should avoid activities that may cause cuts } \\
\text { (contact sports, sewing, hard teeth brushing). }\end{array}$ & 70 & 93.3 & 23 & 30.7 & 19 & 6.7 & $83.56 \pm 15.62$ \\
\hline
\end{tabular}




\begin{tabular}{|c|c|c|c|c|c|c|c|}
\hline $\begin{array}{l}\text { - patients should seek urgent medical attention if } \\
\text { severe bleeding }\end{array}$ & 72 & 96.0 & - & - & 3 & 4.0 & \\
\hline $\begin{array}{l}\text { Drug interaction } \\
\text { - Name medications that you shouldn't have while } \\
\text { you are taking OAC } \\
\text { - It is safe to take vitamin supplements and herbal } \\
\text { medicines with this medicine without consulting } \\
\text { your doctor. }\end{array}$ & 35 & $\begin{array}{l}64.0 \\
46.7\end{array}$ & - & 2.7 & 25 & $\begin{array}{l}33.3 \\
53.3\end{array}$ & $56.0 \pm 42.48$ \\
\hline $\begin{array}{l}\text { Food interaction } \\
\text { - List at least two foods that can affect your } \\
\text { anticoagulant therapy (lentils, Dry beans, and } \\
\text { kiwis ) } \\
\text { - List at least two leafy green vegetables that can } \\
\text { reduce the effect of OAC } \\
\end{array}$ & 13 & $\begin{array}{r}0.0 \\
17.3\end{array}$ & 2 & 2.7 & 73 & $\begin{array}{l}97.3 \\
66.7\end{array}$ & $13.33 \pm 20.27$ \\
\hline $\begin{array}{l}\text { INR Monitoring } \\
\text { - Do you know what the INR test measures? } \\
\text { - Name } 2 \text { problems that may develop if abnormal } \\
\text { INR results. } \\
\text { - The international normalized ratio level should be } \\
\text { checked at least once every four weeks }\end{array}$ & $\begin{array}{l}43 \\
18 \\
59\end{array}$ & $\begin{array}{l}57.3 \\
24.0 \\
78.7\end{array}$ & 14 & $\begin{array}{l}12.0 \\
18.7\end{array}$ & $\begin{array}{l}23 \\
43 \\
16\end{array}$ & $\begin{array}{l}30.7 \\
57.3 \\
21.3\end{array}$ & $58.44 \pm 31.29$ \\
\hline Overall knowledge mean \% score & \multicolumn{7}{|c|}{$59.72 \pm 11.26$} \\
\hline
\end{tabular}

Table (3), Fig (1) Presents that more than half of the studied patients (58.7\%) have high knowledge related to OAC information. Also, $70.7 \%$ of the studied patients have high level of knowledge related to drug precautions, while only one third of them have high knowledge related to drug monitoring ie: international normalized ratio level (INR). On the other hand, the majority of the studied patients have low knowledge related to food interaction, and drug side effects $(80.0 \%, 69.3 \%$ respectively). The overall knowledge score of the majority of patients $(66.7 \%)$ is moderate, and the overall mean percent knowledge score of the studied patients is $59.72 \pm 11.26$.

Table (3): Distribution of the studied patients according to their level of knowledge related to OAC $(\mathrm{n}=75)$

\begin{tabular}{|c|c|c|c|c|c|c|c|c|}
\hline \multirow[t]{2}{*}{ Area of patients' knowledge } & \multicolumn{2}{|c|}{ Low } & \multicolumn{2}{|c|}{ Moderate } & \multicolumn{2}{|c|}{ High } & \multirow{2}{*}{$\begin{array}{c}\text { Total score } \\
\text { Mean } \pm \text { SD. }\end{array}$} & \multirow{2}{*}{$\begin{array}{c}\text { Percent score } \\
\text { Mean } \pm \text { SD. }\end{array}$} \\
\hline & No. & $\%$ & No. & $\%$ & No. & $\%$ & & \\
\hline Drug information & 2 & 2.6 & 29 & 38.7 & 44 & 58.7 & $11.0 \pm 2.11$ & $78.57 \pm 15.04$ \\
\hline Drug Side effect & 52 & 69.3 & 16 & 21.4 & 7 & 9.3 & $0.40 \pm 0.66$ & $20.0 \pm 32.88$ \\
\hline Drug Precautions & 2 & 2.7 & 20 & 26.6 & 53 & 70.7 & $5.01 \pm 0.94$ & $83.56 \pm 15.62$ \\
\hline Drug interaction & 24 & 32.0 & 19 & 25.3 & 32 & 42.7 & $2.24 \pm 1.70$ & $56.0 \pm 42.48$ \\
\hline Food interaction & 60 & 80.0 & 15 & 20.0 & 0 & 0.0 & $0.53 \pm 0.81$ & $13.33 \pm 20.27$ \\
\hline Monitoring (INR) & 25 & 33.4 & 25 & 33.3 & 25 & 33.3 & $3.51 \pm 1.88$ & $58.44 \pm 31.29$ \\
\hline Overall score of knowledge & 10 & 13.3 & 50 & 66.7 & 15 & 20.0 & $22.69 \pm 4.28$ & $59.72 \pm 11.26$ \\
\hline
\end{tabular}

Low knowledge $(>50 \%)$. Moderate knowledge $(50<75 \%) \quad$ High knowledge $(\geq 75 \%)$

Figure (1) Distribution of the studied patients according to their level of knowledge related to OAC $(n=75)$

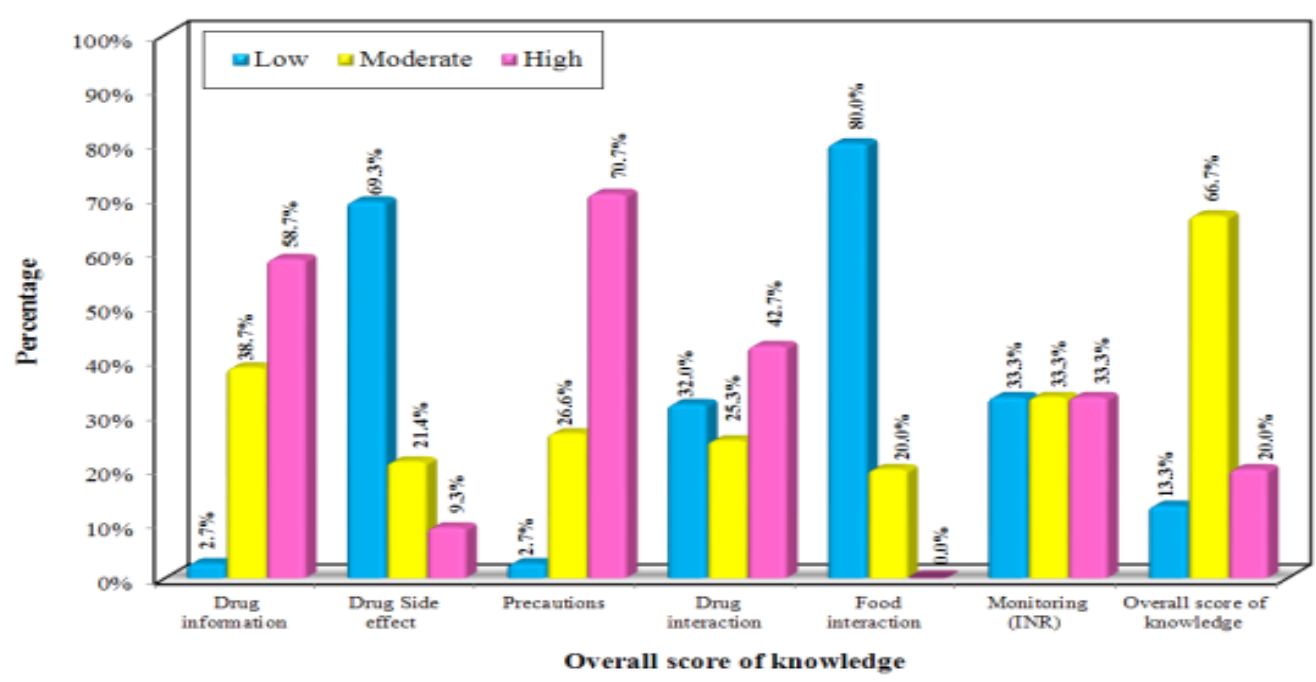


Table (4) Depicts that about two third of the studied patients (64\%) delay OAC, and less than half of them forget to take the drug, and skip the due date of INR analysis $(46.7 \%, 42.6 \%)$. Also, more than quarter $(25.3 \%)$ of the studied patients have problems in remembering to take their OAC medication. However, less than half of the studied patients have either satisfactory or good adherence levels (42.7\%, and $44 \%$ respectively).

Table (4): Distribution of the studied patients according to their level of adherence related to OAC $(\mathrm{n}=75)$

\begin{tabular}{|c|c|c|c|c|}
\hline \multirow{2}{*}{ Adherence related to $\mathrm{OAC}(\mathrm{n}=75)$} & \multicolumn{2}{|c|}{ Yes } & \multicolumn{2}{|c|}{ No } \\
\hline & No. & $\%$ & No. & $\%$ \\
\hline - Do you ever delayed OAC intake within the previous month & 48 & 64.0 & 27 & 36.0 \\
\hline - Do you ever forgot to take a OAC dose within the previous month & 35 & 46.7 & 40 & 53.3 \\
\hline - Do you ever took an overdose of OAC within the previous month & 0 & 0.0 & 75 & 100.0 \\
\hline - Do you ever have problems in remembering to take your OAC? & 19 & 25.3 & 56 & 74.7 \\
\hline - Do you sometimes (When you feel better) stop taking/ reduce the dose of OAC? & 13 & 17.3 & 62 & 82.7 \\
\hline - Do you skipped the due date of INR analysis for the last month & 32 & 42.7 & 43 & 57.3 \\
\hline $\begin{array}{l}\text { Total score } \\
\% \text { score }\end{array}$ & \multicolumn{4}{|c|}{$\begin{array}{c}\text { Mean } \pm \text { SD }(4.07 \pm 1.40) \\
\text { Mean } \pm \text { SD }(67.78 \pm 23.3)\end{array}$} \\
\hline \begin{tabular}{|l|} 
Unsatisfactory \\
Satisfactory \\
Good adherence
\end{tabular} & & & & \\
\hline
\end{tabular}

Unsatisfactory level of adherence $(<50 \%), \quad$ Satisfactory $(50 \geq 75 \%), \quad$ Good $(>75 \%)$

Table (5), Fig (2) displays that there are positive significant correlations between patients' adherence to OAC and their level of knowledge $\left(r=0.597^{*}, \mathrm{p}=<0.001^{*}\right.$.

Table (5): Pearson correlation coefficient between patients' adherence to OAC and their overall knowledge score $(n=75)$

\begin{tabular}{|c|c|c|c|c|c|c|c|c|}
\hline \multirow{3}{*}{ Overall knowledge score } & \multicolumn{6}{|c|}{ Patients' adherence to OAC } & \multirow{3}{*}{$\mathbf{R}$} & \multirow{3}{*}{$\mathbf{p}$} \\
\hline & \multicolumn{2}{|c|}{$\begin{array}{c}\text { Unsatisfactory } \\
(\mathbf{n}=\mathbf{1 0})\end{array}$} & \multicolumn{2}{|c|}{$\begin{array}{l}\text { Satisfactory } \\
\quad(\mathbf{n}=\mathbf{3 2})\end{array}$} & \multicolumn{2}{|c|}{$\begin{array}{c}\text { Good } \\
\text { adherence } \\
(\mathbf{n}=\mathbf{3 3})\end{array}$} & & \\
\hline & No. & $\%$ & No. & $\%$ & No. & $\%$ & & \\
\hline Low & 5 & 50.0 & 4 & 12.5 & 1 & 3.0 & & \\
\hline Moderate & 5 & 50.0 & 25 & 78.1 & 20 & 60.6 & $0.597^{*}$ & $<0.001^{*}$ \\
\hline High & 0 & 0.0 & 3 & 9.4 & 12 & 36.4 & & \\
\hline
\end{tabular}

r: Pearson coefficient

*: Statistically significant at $\mathrm{p} \leq 0.05$

Figure (2): Pearson correlation coefficient between patients' adherence to OAC and their overall knowledge score $(n=75)$

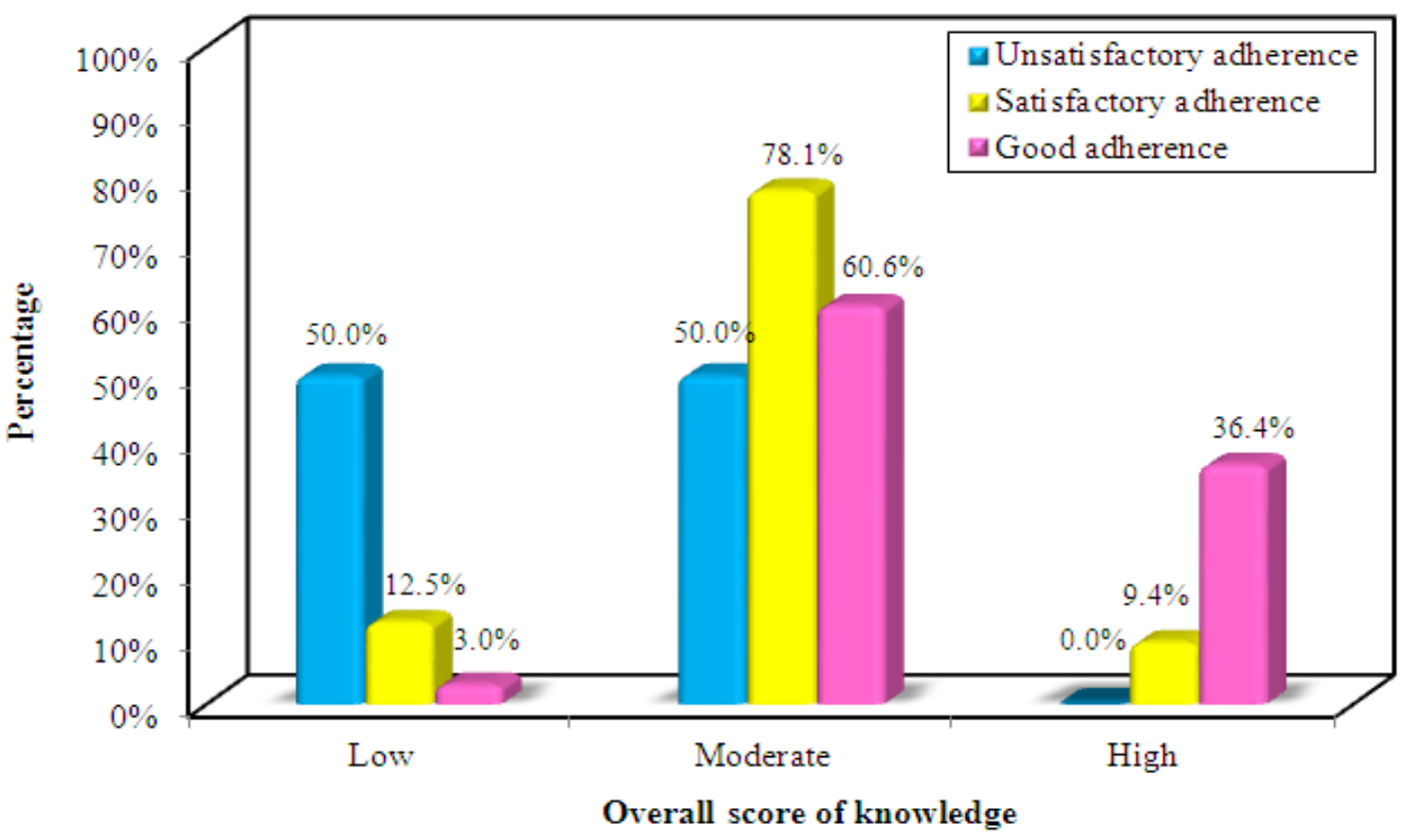


Table (6) Illustrates that there are high significant relationships between patient's age, sex, as well as educational level and their level of knowledge $\left(\chi 2=15.744 * \& \mathrm{p}=0.003 *, \chi 2=9.984 * \& \mathrm{p}=0.007 * \&\left(\chi 224.758^{*}=\right.\right.$ $\& \mathrm{p}<0.001 *$ respectively), where almost all patients $(95.5 \%)$ are between $30-45$ years, and the majority of female patients $(76.2 \%)$ have moderate level of knowledge. All patients with bachelor degree have high level of knowledge. In addition, there are significant differences between patient occupation and their level of knowledge, as the majority of housewives (77.4\%) have moderate level of knowledge. Also all patients' received OAC education have moderate to high knowledge, which is significantly high, where $\square \chi^{2}=.21 .158^{*}$, $\left.\mathrm{p}<0.001^{*}\right)$. There are no significance differences between the rest of socio-demographic characteristics and patient's level of knowledge.

Table (6): Relationships between patients' overall knowledge score and their socio-demographic and clinical characteristics $(\mathrm{n}=75)$

\begin{tabular}{|c|c|c|c|c|c|c|c|c|}
\hline \multirow{3}{*}{$\begin{array}{l}\text { socio-demographic and } \\
\text { clinical characteristics }\end{array}$} & \multicolumn{6}{|c|}{ Overall knowledge score } & \multirow{3}{*}{$\chi^{2}$} & \multirow{3}{*}{${ }^{\mathrm{MC}} \mathrm{p}$} \\
\hline & \multicolumn{2}{|c|}{$\begin{array}{c}\text { Low } \\
(\mathbf{n}=10)\end{array}$} & \multicolumn{2}{|c|}{$\begin{array}{c}\text { Moderate } \\
(\mathbf{n}=\mathbf{5 0})\end{array}$} & \multicolumn{2}{|c|}{$\begin{array}{c}\text { High } \\
(\mathbf{n}=15)\end{array}$} & & \\
\hline & No. & $\%$ & No. & $\%$ & No. & $\%$ & & \\
\hline \begin{tabular}{|l} 
Age (years) \\
$20-30$ \\
$30-45$ \\
$45-60$ \\
\end{tabular} & $\begin{array}{c}0 \\
0 \\
10\end{array}$ & $\begin{array}{c}0.0 \\
0.0 \\
23.8\end{array}$ & $\begin{array}{c}8 \\
21 \\
21\end{array}$ & $\begin{array}{l}72.7 \\
95.5 \\
50.0\end{array}$ & $\begin{array}{c}3 \\
1 \\
11 \\
\end{array}$ & $\begin{array}{c}27.3 \\
4.5 \\
26.2 \\
\end{array}$ & $15.744^{*}$ & $0.003^{*}$ \\
\hline \begin{tabular}{|l|} 
Sex \\
Male \\
Female
\end{tabular} & $\begin{array}{l}3 \\
7\end{array}$ & $\begin{array}{c}9.1 \\
16.7\end{array}$ & $\begin{array}{l}18 \\
32\end{array}$ & $\begin{array}{l}54.5 \\
76.2\end{array}$ & $\begin{array}{c}12 \\
3\end{array}$ & $\begin{array}{c}36.4 \\
7.1\end{array}$ & $9.984^{*}$ & $0.007^{*}$ \\
\hline $\begin{array}{l}\text { Education level } \\
\text { Illiterate } \\
\text { Read, write } \\
\text { Diploma } \\
\text { Bachelor }\end{array}$ & $\begin{array}{l}4 \\
3 \\
3 \\
0\end{array}$ & $\begin{array}{c}13.8 \\
13.6 \\
17.6 \\
0.0\end{array}$ & $\begin{array}{c}23 \\
14 \\
13 \\
0\end{array}$ & $\begin{array}{c}79.3 \\
63.6 \\
76.5 \\
0.0 \\
\end{array}$ & $\begin{array}{l}2 \\
5 \\
1 \\
7\end{array}$ & $\begin{array}{c}6.9 \\
22.7 \\
5.9 \\
100.0\end{array}$ & $24.758^{*}$ & $<0.001^{*}$ \\
\hline $\begin{array}{l}\text { Occupation } \\
\text { Clerical } \\
\text { Technical } \\
\text { Housewife } \\
\text { Retired } \\
\text { Not working }\end{array}$ & $\begin{array}{l}3 \\
3 \\
4 \\
0 \\
0\end{array}$ & $\begin{array}{c}33.3 \\
13.0 \\
12.9 \\
0.0 \\
0.0\end{array}$ & $\begin{array}{c}2 \\
17 \\
24 \\
4 \\
3\end{array}$ & $\begin{array}{l}22.2 \\
73.9 \\
77.4 \\
50.0 \\
75.0\end{array}$ & $\begin{array}{l}4 \\
3 \\
3 \\
4 \\
1\end{array}$ & $\begin{array}{c}44.4 \\
13.0 \\
9.7 \\
50.0 \\
25.0\end{array}$ & $15.145^{*}$ & $0.023^{*}$ \\
\hline $\begin{array}{l}\text { Social status } \\
\text { Single } \\
\text { Married } \\
\text { Divorced } \\
\end{array}$ & $\begin{array}{c}0 \\
10 \\
0 \\
\end{array}$ & $\begin{array}{c}0.0 \\
14.9 \\
0.0\end{array}$ & $\begin{array}{c}3 \\
45 \\
2 \\
\end{array}$ & $\begin{array}{c}50.0 \\
67.2 \\
100.0 \\
\end{array}$ & $\begin{array}{c}3 \\
12 \\
0 \\
\end{array}$ & $\begin{array}{c}50.0 \\
17.9 \\
0.0 \\
\end{array}$ & 3.748 & 0.352 \\
\hline \begin{tabular}{|l} 
Residence \\
Urban \\
Rural
\end{tabular} & $\begin{array}{c}10 \\
0\end{array}$ & $\begin{array}{c}15.4 \\
0.0\end{array}$ & $\begin{array}{l}40 \\
10\end{array}$ & $\begin{array}{c}61.5 \\
100.0\end{array}$ & $\begin{array}{c}15 \\
0\end{array}$ & $\begin{array}{c}23.1 \\
0.0\end{array}$ & 4.816 & 0.066 \\
\hline \begin{tabular}{|l|} 
Duration of anticoagulant \\
usage \\
$>1$ year \\
$1-5$ years \\
$>5$ years \\
\end{tabular} & $\begin{array}{l}7 \\
3 \\
0 \\
\end{array}$ & $\begin{array}{c}20.0 \\
9.1 \\
0.0\end{array}$ & $\begin{array}{c}21 \\
25 \\
4 \\
\end{array}$ & $\begin{array}{l}60.0 \\
75.8 \\
57.1 \\
\end{array}$ & $\begin{array}{l}7 \\
5 \\
3 \\
\end{array}$ & $\begin{array}{l}20.0 \\
15.2 \\
42.9 \\
\end{array}$ & 4.700 & 0.293 \\
\hline $\begin{array}{|ll|}\text { Received } & \text { anticoagulant } \\
\text { education } & \\
\text { Yes } \\
\text { No }\end{array}$ & $\begin{array}{c}0 \\
10\end{array}$ & $\begin{array}{c}0.0 \\
22.7\end{array}$ & $\begin{array}{l}18 \\
32\end{array}$ & $\begin{array}{l}58.1 \\
72.7\end{array}$ & $\begin{array}{c}13 \\
2\end{array}$ & $\begin{array}{c}41.9 \\
4.5\end{array}$ & $21.158^{*}$ & $<0.001^{*}$ \\
\hline
\end{tabular}

$\chi^{2}$ and $p$ values for Chi square test

${ }_{\mathrm{MC}} \mathrm{p}$ : $\mathrm{p}$ value for Monte Carlo for Chi square test

*: Statistically significant at $\mathrm{p} \leq 0.05$

Table (7) Displays that there are high significant relationships between patients' education level and their level of adherence to OAC, all patients with bachelor degree achieved good level of adherence, where $(\chi 2=18.332 \& \mathrm{p}=0.002)$. Also, there are high significant relationships between receiving anticoagulants' education, and patients' level of adherence, as the majority of these patients (71\%) had good level of adherence, where $\square\left(\chi 2=15.994^{*}, \mathrm{p}<0.001 *\right)$. However, there are no significance differences between the rest of socio-demographic characteristics and patients' level of adherence. 
Table (7): Relationships between Patients' adherence to OAC and their socio-demographic and clinical characteristics $(\mathrm{n}=75)$

\begin{tabular}{|c|c|c|c|c|c|c|c|c|}
\hline \multirow{3}{*}{$\begin{array}{l}\text { Socio-demographic and clinical } \\
\text { characteristics }\end{array}$} & \multicolumn{6}{|c|}{ Patients' adherence levels to OAC } & \multirow{3}{*}{$\chi^{2}$} & \multirow{3}{*}{${ }^{\mathrm{MC}} \mathbf{p}$} \\
\hline & \multicolumn{2}{|c|}{$\begin{array}{l}\text { Unsatisfactory } \\
\qquad(\mathbf{n}=\mathbf{1 0})\end{array}$} & \multicolumn{2}{|c|}{$\begin{array}{l}\text { Satisfactory } \\
\quad(\mathbf{n}=\mathbf{3 2})\end{array}$} & \multicolumn{2}{|c|}{$\begin{array}{c}\text { Good } \\
\text { adherence } \\
(\mathbf{n}=\mathbf{3 3})\end{array}$} & & \\
\hline & No. & $\%$ & No. & $\%$ & No. & $\%$ & & \\
\hline \multicolumn{9}{|l|}{ Age (years) } \\
\hline $20-30$ & 1 & 9.1 & 5 & 45.5 & 5 & 45.5 & \multirow{3}{*}{3.477} & \multirow{3}{*}{0.475} \\
\hline $30-45$ & 1 & 4.5 & 12 & 54.5 & 9 & 40.9 & & \\
\hline $40-65$ & 8 & 19.0 & 15 & 35.7 & 19 & 45.2 & & \\
\hline \multicolumn{9}{|l|}{ Sex } \\
\hline Male & 5 & 15.2 & 11 & 33.3 & 17 & 51.5 & \multirow{2}{*}{2.106} & \multirow{2}{*}{0.349} \\
\hline Female & 5 & 11.9 & 21 & 50.0 & 16 & 38.1 & & \\
\hline \multicolumn{9}{|l|}{ Education level } \\
\hline Illiterate & 2 & 6.9 & 16 & 55.2 & 11 & 37.9 & \multirow{4}{*}{$18.332^{*}$} & \multirow{4}{*}{$0.002^{*}$} \\
\hline Read, write & 2 & 9.1 & 8 & 36.4 & 12 & 54.5 & & \\
\hline Diploma & 6 & 35.3 & 8 & 47.1 & 3 & 17.6 & & \\
\hline Bachelor & 0 & 0.0 & 0 & 0.0 & 7 & 100.0 & & \\
\hline \multicolumn{9}{|l|}{ Occupation } \\
\hline Clerical & 3 & 33.3 & 2 & 22.2 & 4 & 44.4 & \multirow{5}{*}{11.669} & \multirow{5}{*}{0.116} \\
\hline Technical & 4 & 17.4 & 6 & 26.1 & 13 & 56.5 & & \\
\hline Housewife & 2 & 6.5 & 18 & 58.1 & 11 & 35.5 & & \\
\hline Retired & 0 & 0.0 & 5 & 62.5 & 3 & 37.5 & & \\
\hline Not working & 1 & 25.0 & 1 & 25.0 & 2 & 50.0 & & \\
\hline \multicolumn{9}{|l|}{ Social status } \\
\hline Single & 0 & 0.0 & 3 & 50.0 & 3 & 50.0 & \multirow{3}{*}{2.802} & \multirow{3}{*}{0.654} \\
\hline Married & 10 & 14.9 & 27 & 40.3 & 30 & 44.8 & & \\
\hline Divorced & 0 & 0.0 & 2 & 100.0 & 0 & 0.0 & & \\
\hline \multicolumn{9}{|l|}{ Residence } \\
\hline Urban & 9 & 13.8 & 27 & 41.5 & 29 & 44.6 & \multirow{2}{*}{0.310} & \multirow{2}{*}{0.899} \\
\hline Rural & 1 & 10.0 & 5 & 50.0 & 4 & 40.0 & & \\
\hline \multicolumn{9}{|l|}{ Duration of OAC usage } \\
\hline$>1$ year & 4 & 11.4 & 18 & 51.4 & 13 & 37.1 & \multirow{3}{*}{2.466} & \\
\hline $1-5$ years & 5 & 15.2 & 12 & 36.4 & 16 & 48.5 & & 0.674 \\
\hline$<5$ years & 1 & 14.3 & 2 & 28.6 & 4 & 57.1 & & \\
\hline Received anticoagulant education & & & & & & & & \\
\hline Yes & 3 & 9.7 & 6 & 19.4 & 22 & 71.0 & $15004^{*}$ & $<0 \Omega 01$ * \\
\hline No & 7 & 15.9 & 26 & 59.1 & 11 & 25.0 & & \\
\hline
\end{tabular}

$\chi^{2}$ and $\mathrm{p}$ values for Chi square test

${ }^{\mathrm{MC}} \mathrm{p}$ : $\mathrm{p}$ value for Monte Carlo for Chi square test

*: Statistically significant at $\mathrm{p} \leq 0.05$

\section{Discussion}

The purpose of this study was to determine knowledge and adherence to oral anticoagulant therapy among patients with mechanical heart valve prosthesis. The current study revealed that the majority of the studied patients had moderate overall knowledge score related to OAC. However, the results of this study differ from $\mathrm{Hu}$ et al (2006) who evidenced the poor knowledge level of the majority of patients with mechanical valve prostheses regarding $\mathrm{OAC}^{[28]}$.

The majority of patients in our study stated that they had not received education related to OAC, and physicians were the main source of this education. Nurses never educated their patients regarding OAC usage. In this context, korkmaz et al (2015) found that nurses instructed the majority of their patients about OAC, and added that patient education regarding medication is the main responsibility of nurses ${ }^{[23]}$. However, Abd ElNaby et al (2014) reported that doctors and nurses usually neglect patients' education related to OAC because of lack of their time, and the overwhelming nature of education from patients' point of view ${ }^{[20]}$. Leeper et al (2009) reported that mechanical heart valve patients and their families should be instructed regarding the use of OAC as it enhances their understanding of the drug precautions and complications ${ }^{[29]}$.

In addition, the present study showed that the majority of the patients were not able to mention side effect of OAC, while the majority of them had high level of knowledge related to drug precautions. Nevertheless, Ansell et al (2001) found that nearly one fifth of anticoagulant patients were able to name one or more of the side effects of OAC ${ }^{[30]}$. However, Rocha et al (2010) found the majority of patients included in their study presented regular knowledge concerning OAC side effects, and drug precautions ${ }^{[24]}$. 
OAC - food interaction is critical issue that nurses should instruct their patients about. Our findings indicated that the majority of patients had low knowledge related to diet rich in vitamin K. korkmaz et al (2015) , and $\mathrm{Hu}$ et al (2006) found similar finding, as the majority of their patients had poor knowledge regarding nutrition and vitamin K sources ${ }^{[23,28]}$. Similar findings were reported by Henn et al (2008) who found that the majority of patients had low knowledge about the influence of diet on OAC ${ }^{[31]}$.

In addition, the results of the present study showed that the majority of the studied patients mentioned monthly laboratory control as the main necessary care. In the same vein, Rocha (2010) reported that periodical follow up of INR levels is mandatory for patients with mechanical heart valve prosthesis ${ }^{[24]}$.

The current study revealed that the majority of the studied patients delayed OAC, and less than half of them forget to take the drug, and skipped the due date of INR analysis. However, less than half of the studied patients had either satisfactory or good adherence levels to their prescribed OAC. This could be related to the nature of the disease that necessitates drug adherence to avoid major complications. Contrary to our findings, Omair et al (2016) found that few patients had high adherence to OAC therapy ${ }^{[12]}$.

The current study has highlighted the positive significant correlations between patients' adherence to OAC and their level of knowledge. This could be interpreted that more educated patients are more understanding of the drug complications, which enhance their adherence. In this context, Rocha (2010) mentioned that Adherence to OAC is influenced directly by patients' knowledge about the therapy ${ }^{[24]}$. These results go on the same line with Wang et al (2014) who found that there were associations between better knowledge and higher ACO adherence ${ }^{[26]}$. Also, Kim et al (2011) reported that patients' knowledge about OAC is significantly affecting their adherence ${ }^{[27]}$. Contradicting our results, Omair et al (2016) found that there were no association between the patients' knowledge, and their adherence to OAC ${ }^{[12]}$.

On studying the relationships between patients' demographics and their level of knowledge related to $\mathrm{OAC}$, the study findings showed that there were high significant relationships between patient's age, and their level of knowledge, as patients in the middle age had moderate level of knowledge. Omair et al (2016) found that patients, who had fair knowledge, were in the middle age group ${ }^{[12]}$. Also, McCabe et al (2008) added that patient's knowledge decline with advanced age ${ }^{[32]}$.

The findings displayed that there were high significant relationships between patients' educational level, and their level of knowledge. Similar results were reported by korkmaz et al (2015) who found that university graduates had higher level of knowledge related to OAC therapy ${ }^{[23]}$. Many researchers supported our results, as they found correlations between patients' knowledge about OAC, and their level of education ${ }^{[33,34,35]}$. Also, Omair et al (2016) found that patients who achieved fair knowledge, had high education, although knowledge's association with level of education was insignificant ${ }^{[12]}$.

Furthermore, the majority of patients in the present study, who achieved moderate level of knowledge, were females, which is highly significant. In this regard, Omair et al (2016) found significant associations between patients' sex, and level of knowledge, as female patients achieved fair knowledge than males ${ }^{[12]}$. On the other hand, McCabe et al (2008) found that there were no significant associations between patients' gender, and level of knowledge ${ }^{[32]}$. In addition, the present study revealed that the majority of housewives had moderate level of knowledge and these correlations were significant. Concerning occupation differences, Rocha (2010) found that there were no relationships between patients' occupation and knowledge score ${ }^{[24]}$.

Patients' Adherence to OAC therapy is governed by many factors, as age, sex, and level of education. The current study findings revealed that there were significant differences between patients' educational level, and their level of adherence to OAC. This is contradicted by Omair et al (2016) who found that illiterate/ low educated patients were highly adherent with their OAC therapy, and these correlations were significant ${ }^{[12]}$.

The present study findings showed high significant relationships between receiving anticoagulants education, and both patients' level of knowledge and adherence. This could be interpreted by the fact that education improves patients' understanding, as educated patients are keener to adhere to treatment regimen. However, there were no significance differences between patient's sex/age and their level of adherence. Contrary to our findings, Omair et al (2016) found high adherence in males more than females, and the old age patients were highly adherent to OAC ${ }^{[12]}$.

An important factor in OAC therapy success is adherence of patients, which is based on adequate knowledge to avoid serious complications. Our study revealed moderate level of patients' overall knowledge related to OAC. Moreover, less than half of the studied patients had either satisfactory or good adherence levels. Nurses have a key role in patient's adherence to OAC, as they are in close contact with their patients 24 hours a day. Effective nursing role as educator to patients receiving OAC therapy may improve the adherence to therapy and prevent the development of fatal complications.

DOI: 10.9790/1959-0603021929 $\quad$ www.iosrjournals.org $\quad 27 \mid$ Page




\section{Conclusion}

On the basis of our study, the majority of the studied patients had moderate overall knowledge score about OAC, and less than half of them had either satisfactory or good adherence levels $(42.7 \%$, and $44 \%$ respectively). Results highlighted positive significant correlations between patients' adherence to OAC and their level of knowledge $\left(\mathrm{r}=0.597^{*}, \mathrm{p}=<0.001^{*}\right)$. In addition, there were significant differences between patient's education, sex, occupation and their level of knowledge, whereas no significance differences between patient's sex/age and their level of adherence were found

\section{Recommendations}

- An instructional program for patients and their families should be developed to improve their knowledge, adherence, as well as reduce incidence of OAC side effects prior to their discharge from the hospital.

- An in-service educational program regarding OAC therapy should be provided for nurses working at the cardiovascular care units to update their knowledge and practice about OAC therapy.

- Provision of educational units in undergraduate nursing courses related to OAC therapy.

- Implementing further studies, using a larger sample from different settings.

References

[1]. World Health Organization. Cardiovascular diseases Fact sheet, Reviewed September $2016 . \quad$ Available at http://www.who.int/mediacentre/factsheets/fs317/en/ Retrieved 5/4/2017.

[2]. Rostami H, Ghahramanian A, Golchin M. Educational needs of myocardial infarction patients. Journal of Urmia Nursing And Midwifery Faculty. 2011;9(3):157-64.

[3]. World Health Organization - Non-communicable Diseases (NCD) Country Profiles , 2014. Available athttp://www.who.int/nmh/publications/ncd-profiles-2014/en/ Retrieved 5/4/2017.

[4]. Nkomo VT, Gardin JM, Skelton TN, Gottdiener JS, Scott CG, Enriquez-Sarano.Burden of valvular heart diseases: a populationbased study. Lancet. 2006 Sep;368(9540):1005-11.

[5]. Kovacs AH, Harrison JL, Colman JM, Sermer M, Siu SC, Silversides CK. Pregnancy and contraception in congenital heart disease: what women are not told. J Am CollCardiol. 2008;52(7):577.

[6]. Taqaddosi M, AbdarEsfahani M, Musavi S. Difficulties of patients with replaced heart valve in Kashan, 2001. Feyz, Journal of Kashan University of Medical Sciences. 2005;9(2):62-9.

[7]. Bonow RO, Carabello BA, Kanu C, et al. ACC/AHA 2006 guidelines for the management of patients with valvular heart disease: a report of the American Collegeof Cardiology/American Heart Association Task Force on Practice Guidelines(writing committee to revise the 1998 Guidelines for the Management of Patients With Valvular Heart Disease): developed in collaboration with the Society of Cardiovascular Anesthesiologists: endorsed by the Society for Cardiovascular Angiography and Interventions and the Society of Thoracic Surgeons. Circulation 2006;114:e84-231.

[8]. Vahanian A, Baumgartner H, Bax J, et al. Guidelines on the management of valvular heart disease: The Task Force on the Management of Valvular Heart Disease of the European Society of Cardiology. Eur Heart J 2007;28:230-68.

[9]. Kulik, A., et al. Early Postoperative Anticoagulation after Mechanical Valve Replacement: A Canadian Survey.J.of Heart Valve Disease 2006;15: 581.

[10]. The International Warfarin Pharmacogenetics Consortium. Estimation of the Warfarin Dose with Clinical and Pharmacogenetic Data. N Engl J. Med.2009; 360:753-764.

[11]. Roche-Nagle G, Chambers F, Nanra J, Bouchier-Hayes D, Young S. Evaluation of patient knowledge regarding oral anticoagulants. Ir Med J 2003;96:211-3.

[12]. Omair S, Musallam N, Deghaither N, Al-Sadoun N, Bayoumy N. Compliance with and awareness about long-term oral anticoagulant therapy among Saudi patients in a University Hospital, Riyadh, Saudi Arabia. J. Applied Hematology2016;(7):1.

[13]. Field TS, Jennifer T, Mazor KM, Donovan JL, Kanaan AO, Harrold LR, Reed G, Doherty P, SpenardA, Gurwitz JH. Randomized trial of a warfarin communication protocol for nursing homes: an SBAR-based approach. Am J. Med.2011; 124: 179.e1-179.e7.

[14]. Popp SK. Warfarin safety for residents in skilled nursing facilities. ACPHS 2013. available at: www.thefqc.org/.../2013/.../Warfarin-Study-Abstract dr.

[15]. Smith MB, Christensen N, Wang S, Strohecker J, Day JD, Weiss JP, Crandall BG, Osborn JS, Anderson JL, Horne BD, Muhlestein JB, Lappe DL, Moss H, Oliver J, Viau K, Bunch TJ. Warfarin Knowledge in Patients with Atrial Fibrillation: Implications for Safety, Efficacy, and Education Strategies. Cardiology 2010;116:61-69.

[16]. Vrijens B, de Geest S, Hughes DA, et al., "A new taxonomy for describing and defining adherence to medications," British Journal of Clinical Pharmacology2012; 73(5): 691-705.

[17]. Kumari MJ, Amirthavalli A, Dhananchezhian K, Jennifer D, Elakkia G, MathumalarN, Sangeetha M, Santhi G, Sreevastha D. Assessment of Knowledge on Oral Anticoagulation Therapy among Valve Replacement Patients. Inter J. Advanced Research 2015; 3(4): 1236-1243.

[18]. Brown M, Bussell J. “Medication adherence:WHOcares?”Mayo Clinic Proceedings 2011; 86(4): 304-314.

[19]. Johnson M, Williams M, Marshall E. "Adherent and nonadherent medication-taking in elderly hypertensive patients," Clinical Nursing Researc h 1999; 8(4):318-335.

[20]. Abd El-Naby AG, Hashem HY, Ismail GM. Evaluation of a Designed Warfarin Educational Program on Patients' Knowledge and Incidence of Side Effects. Global Journal of Pharmacology 2014;8 (4): 592-600.

[21]. Lam WY, Fresco P. Medication Adherence Measures: An Overview. Bio Med Research International 2015; Article ID 217047, 12 pages.

[22]. Karch A.M., Focus on nursing pharmacology. Lippincott Williams \&Wilkins, New York 2008;20:177-192. pp:790-794.

[23]. Korkmaz F, Alcan A, and Karacabay K. Do patients with mechanical heart valves have the appropriate knowledge regarding warfarin therapy and can they adhere to the correct dosage?

[24]. Rocha H, Rabelo E, Aliti G, and de Souza E Knowledge of Patients with Mechanical Valve Prostheses Concerning Chronic Oral Anticoagulant Therapy. Rev. Latino-Am. Enfermagem 2010 Jul-Aug; 18(4): 696-702. 
[25]. Eltayeb T, Mohamed M, Elbur A , and Elsayed A. Satisfaction with and adherence to warfarin treatment: A cross-sectional study among Sudanese patients. J Saudi Heart Assoc. (http://creativecommons.org/licenses/by-nc-nd/4.0/).

[26]. Wang Y, Kong MC, Lee LH, Ng HJ, Ko Y. Knowledge, satisfaction, and concerns regarding warfarin therapy and their association with warfarin adherence and anticoagulation control. Thromb Res 2014;133:550-4.

[27]. Kim JH, Kim GS, Kim EJ, Park S, Chung N, Chu SH. Factors affecting medication adherence and anticoagulation control in Korean patients taking warfarin. J CardiovascNurs 2011;26:466-74.

[28]. Hu A, Chow CM, Dao D, Errett L, Keith M. Factors influencing patient knowledge of warfain therapy after mechanical heart valve replacement. J CardiovascNurs. 2006; 21(3):169-75.

[29]. Leeper B. Valvular disease and surgery. In: Carlson KK, editor. Advanced critical care nursing. St. Louis: Elsevier; 2009. p. 32246.

[30]. Ansell J, Hirsh J, Dalen J, Bussey H, Anderson D, Poller L, et al. Managing oral anticoagulant therapy. Chest. 2001;119Suppl: $22 \mathrm{~S}-38 \mathrm{~S}$.

[31]. Henn CB, Rabelo ER, Boaz M, Souza EN. Conhecimento dos pacientes sobre anticoagulação oral crônica acompanhado sem ambulatórioespecializado. Rev GaúchEnferm. 2008;29(2):207-13.

[32]. McCabe PJ, Schad S, Hampton A, Holland DE. Knowledge and self management behaviors of patients with recently detected atrial fibrillation. Heart Lung 2008;37:79-90.

[33]. Yahaya AM, Hassali MA, Awaisu A, Shafie AA. Factors associated with warfarin therapy knowledge and anticoagulation control among patients attending a warfarin clinic in Malaysia. J Clin Diagn Res 2009;3:1663-70.

[34]. Khudair IF, Hanssens YI. Evaluation of patients' knowledge on warfarin in outpatient anticoagulation clinics in a teaching hospital in Qatar. Saudi Med J 2010;31:672-7.

[35]. Guzman C, Blostein M, Tabah A, Muladzanov A, Kahn S. Patients' knowledge of anticoagulation and its association with clinical characteristics, INR control and warfarin-related adverse events. Blood 2013;122:1738. 